\title{
PENCEMARAN UDARA DI PERKOTAAN BERDAMPAK BAHAYA BAGI MANUSIA, HEWAN, TUMBUHAN DAN BANGUNAN
}

\author{
Muhammad Yasir \\ Program Studi Pendidikan IPS Fakultas Keguruan dan Ilmu Pendidikan \\ Universitas Lambung Mangkurat \\ Banjarmasin \\ e-mail: 2010128110002@mhs.ulm.ac.id
}

\begin{abstract}
Abstrak
Masalah lingkungan merupakan suatu peristiwa yang berdampak pada kehidupan manusia dan masyarakat sosial. Permasalahan lingkungan dapat terjadi akibat ulah tangan manusia maupun dari sumber alami. Permasalahan lingkungan yang terjadi diperkotaan diantaranya iyalah polusi udara atau pencemaran udara. Pencemaran udara terjadi akibat banyaknya zat fisik, kimia atau biologi yang berada dalam atmosfersecara bersamaan dan jumlah yang banyak. Sehingga hal itu berdampak pada kehidupan manusia, seperti dalam hal kesehatan tubuh manusia, hewan maupun tumbuhan, mengganggu kenyamanan serta merusak properti. Udara merupakan suatu yang sangat penting bagi kehidupan seтиa makhluk hidup.Untuk itu menjaga kestabilan udara merupakan sesuatu yang harus dilakukan. Dengan mencari, membaca dan memahami karya ilmiah yang berkaitan dengan pencemaran udara. Maka terdapatlah berbagai upaya-upaya untuk menangani pencemaran udara harus dilakukan, sehingga terciptanya udara yang sehat dan membuat nyaman. Diantaranya yaitu pembangunan ruang terbuka hijau, gedung hijau, pembangunan permukiman berkelanjutan hingga menangani masalah transportasi dengan cara menggunakan bahan bakar yang lebih aman terhadap lingkungan.
\end{abstract}

Kata Kunci: Permasalan lingkungan, pencemaran, udara, perkotaan

\section{PENDAHULUAN}

Indonesia merupakan sebuah negara yang memiliki jumlah penduduk yang banyak. Seiring dengan berjalannya waktu perkembangan manusia terus bertambah dan meningkat, baik dari sistem ekonomi, sosial, maupun pemerintahan. Dengan besarnya jumlah penduduk, suatu perkotaan menjadi tempat yang paling banyak dihuni. Yang bisa dibilang masyarakat desa banyak mengadu nasib atau merantau ke perkotaan. Semakin banyaknya penduduk di perkotaan, semakin banyak juga perbedaan pendapat hingga permasalahannya. Dengan kemajuan ilmu pengetahuan dan teknologi, begitu banyak perubahan yang terjadi. Baik dari segi sosial maupun ekonomi (Budiyono A, 2010).

Merujuk pada perkotaan, masalah pada lingkungan perkotaan bisa lebih banyak daripada pedesaan. Karena banyaknya penduduk dan juga kebutuhan-kebutuhan yang hanya berguna bagi dirinya sendiri. Masalah lingkungan merupakan suatu peristiwa atau kejadian yang memiliki dampak begitu banyak pada masyarakat perkotaan. Ambil contoh pada permasalahan udara di kota dan di pedesaan. Di pedesaan udara lebih sejuk dan segar dibandingkan dengan perkotaan. Di perkotaan udara cenderung banyak polusinya, akibat ulah manusianya sendiri maupun alami. Akan tetapi ulah manusia lebih banyak dampaknya terhadap lingkungannya. Pencemaran udara ialah hadirnya suatu wujud fisik, kimia ataupun biologi di atmosfer yang membahayakan manusia, hewan dan tumbuhan. 
Penyebab pencemaran udara diantarnya iyalah, kendaraan bermotor, pabrik-pabrik industri, pabrik zat kimia hingga limbah rumah tangga. Semakin banyaknya penduduk, semakin banyak pula alat transportasi yang digunakan. Setiap orang memandang bahwa memili alat transportasi sendiri akan lebih mudah. Akan tetapi dampaknya pun akan sangat meningkat. Banyaknya kendaraan bermotor menimbulkan asap sehingga mengkontaminasi udara yang ada menjadi tercemar. Padahal transportasi umum jauh lebih baik untuk mengurangi polusi udara yang dihasilkan. Banyak nya alat transportasi pribadi, tidak hanya menyebabkan polusi udara hal itu juga menyebabkan kemacetan. Sehingga di kota-kota besar sering mengalami hal yang sedemikian itu.

Dampak pencemaran udara begitu berbahaya bagi manusia, hewan, tumbuhan bahkan material yang ada di alam. Pencemaran udara tentunya berpengaruh pada kesehatan, kenyamanan hingga ketenangan dalam menjalani kehidupan baik bagi manusia atau makhluk lainnya. Tapi yang paling berdampak ya, pada manusia itu sendiri, dan juga penyebabnya ulahnya manusia itu sendiri. Manusia sebagai makhluk yang dibekali akal dan juga pikiran seharusnya dapat berperan penting dalam menjaga kelestarian lingkungannya. Sehingga manusia melakukan beragam upaya untuk mengatasi polusi udara. Untuk memahami berbagai upaya yang dilakukan maka penelitian ini dilakukan. Upaya tersebut diantaranya yaitu pembangunan ruang terbuka hijau, gedung hijau hingga menangani masalah transportasi dengan cara menggunakan bahan bakar yang lebih aman terhadap lingkungan.

\section{METODE}

Metode yang digunakan pada penulisan artikel ini ialah pendekatan deskriptif kualitatif yang digunakan dalam metode kepustakaan atau studi literatur yaitu dengan cara mencari, menelaah dan memahami data-data sepeeti isi buku-buku, dokumen, atau jurnal-jurnal ilmiah lainnya yang relevan dan mendukung untuk menggambarkan atau menjelaskan mengenai faktor penyebab dan dampak serta upaya mengatasi permasalahan lingkungan yang ditimbulkan dari permasalahan pencemaran udara. Sumber data yang digunakan pada penulisan ini didapatkan dari sumber ilmiah yang ada pada google cendikia.

\section{PEMBAHASAN}

Suatu kota merupakan sesuatu tempat tinggal yang relatif besar, padat, serta permanen. Terdiri dari kelompok individu-individu yang berbeda-beda dari segi sosial. Menurut Watt (1973) kota yang sehat ialah apabila terdapat keseimbangan dari berbagai aktivitas. Baik dari segi lingkungan fisik, ekonomi, dan sosialnya. Sebuah kota memiliki peran yang beragam seperti menjadi pusat perkembangan, perekonomian, pemerintah, industri, dan pusat kebudayaan dari suatu wilayah. Suatu hasil penelitian yang telah membuktikan bahwa suhu udara di kota lebih panas daripada lingkungan pedesaan, seperti menjadi sebuah "pulau panas". (Duckworth dan Sandberg (1954) dalam Watt, 1973). 
Jumlah penduduk di kota lebih tinggi daripada penduduk di desa hal itu memungkinkan memunculkan permasalahan lingkungan diperkotaan begitu tinggi, seperti kualitas udara di desa dan di kota amat jauh berbeda. Kualitas udara dipengaruhi oleh berbagai aktivitas manusia dan alam. Buruknya kualitas udara tentunya akan mempengaruhi pada kesehatan masyarakatnya. Pada tahun 2005 bidang transportasi bertanggung jawab atas masuknya 20,7\% dari keseluruhan karbon dioksida dari Indonesia ke atmosfer (Ernawi: 2011). Penggunaan bahan bakar yang tidak ramah akan mempengaruhi lingkungan yang berdampak terhadap rendahnya kualitas udara kota.

Bahan bakar seperti minyak, batu bara atau gas bumi begitu berpengaruh terhadap turunnya kualitas udara di kota, hal ini disebabkan angin yang terbuang ke udara akibat ulah industri, transportasi, perkantoran, dan rumah tangga. Seiring dengan bertambahnya jumlah penduduk, meningkat juga jumlah kendaraan bermotor beroda empat ataupun beroda dua yang disebabkan kemungkinan karena daya beli masyarakat meningkat. Disamping meningkatkya daya beli masyarakat, semakin tinggi pula tingkat polusi akibat emisi alat transportasi. Sumber pencemaran udara lainnya berasal dari pabrik, perkantoran, rumah tangga, dan sampah. Akan tetapi transportasi merupakan penyumbang terbesar terhadap pencemaran udara.

Emisi kendaraan bermotor seperti senyawa kimia berbahaya bagi kesehatan manusia, hewan, tumbuhan serta material sekitarnya. Dari tahun ketahun penggunaan alat transportasi terus meningkat, baik untuk keperluan pribadi maupun sebagai angkutan umum begitu pesat. Sebagai contoh di Indonesia, kota Jakarta memiliki tingkat pencemaran udara sudah pada level pencemaran berat apabila dibandingkan dengan kota lainnya di Indonesia seperti Bandung, Malang, Yogyakarta, Banjarbaru, Bogor dan Barabai. Untuk itu penggunaan kendaraan bermotor diharapkan dikurangi ataupun menggunakan bahan yang lebih ramah lingkungan.

Kawasan perkotaan sebagai tempat tinggal banyak orang mulai menunjukkan penurunan daya dukung lingkungan. Dikarenakan tingginya tingkat pencemaran udara yang dapat mempengaruhi kesehatan masyarakatnya. Pembangunan di kota lebih memfokuskan ke bagian sarana dan prasarana ketimbang lingkungan alam. Sehingga semakin kecilnya ruang terbuka hijau di wilayah perkotaan. Tempat-tempat yang hijau banyak di alih fungsikan menjadi tempat tinggal tempatwisata, pabrik, pertokoan dan lain sebagainya (N. Dahlan, 2004). Hijaunya kota menjadikan kota itu indah dan asri serta sejuk, nyamanan, segar, dan terbebas dari polusi dan kekacauan serta sehat dan cerdasnya masyarakat.

Bersumber pada putusan menteri KLH No. Kep.02/Men-KLH/1988, yang diartikan dengan pencemaran udara ialah masukkannya mahluk hidup, zat, energi atau komponen lain 
ke udara sehingga berubahnya susunan udara. Dan juga oleh aktivitas manusia atau proses alam sehingga kualitas udara menurun sampai pada tahap tertentu yang mengakibatkan udara menjadi kurang bisa berperan lagi sesuai dengan fungsinya. Kerusakan pada udara berarti menurunnya daya dukung alam pada kehidupan yang ada, yang nanti pada waktunya akan mengurangi kualitas kehidupan manusia secara totalitas.

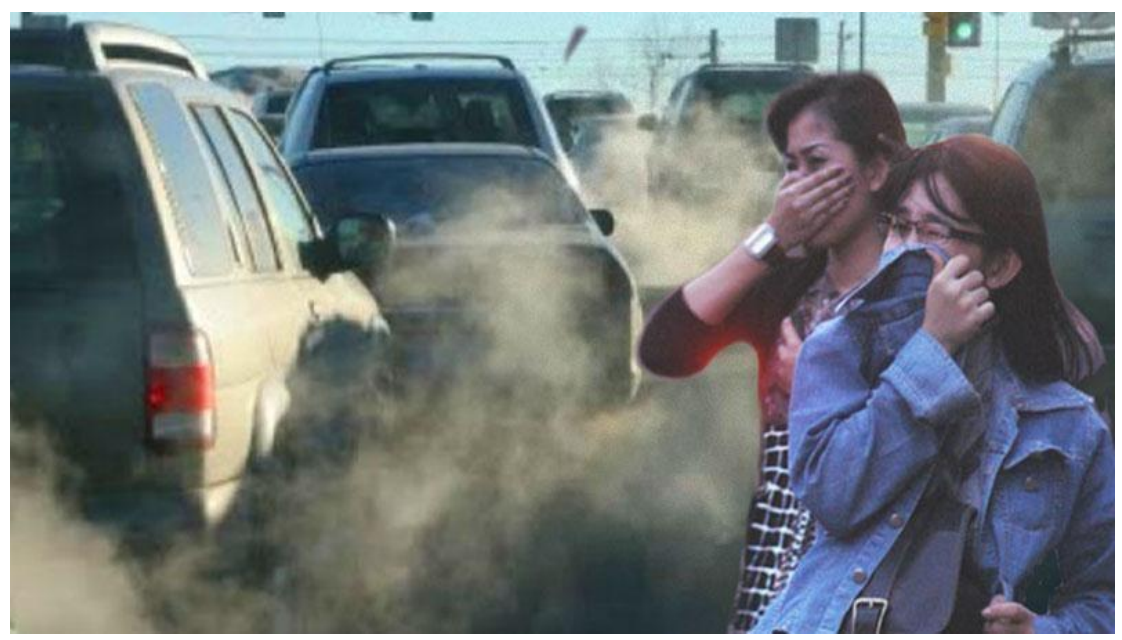

Gambar 1. Pencemaran udara

Manusia merupakan makhluk yang dibekali akal dan juga pikiran, akan tetapi manusia lah yang menjadi penyebab utama dan terbesar terjadinya pencemaran udara. Pencemaran udara merupalan salah satu masalah lingkungan, dimana kualitas udara mengalami penurunan karena masuknya unsur-unsur berbahaya ke dalah atmosfer bumi. Unsur-unsur berbahaya itu diantaranya seperti karbon monoksida, nitrogen dioksida, chlorofluorcarbon, sulfur dioksida, hidrokarbon, benda partikulat, timah, dan carbon diaoksida. Unsur-unsur itu dapat dikatakan juga sebagai polutan atau bahan pencemar udara. Masuknya polutan ke udara menyebabkan pencemaran udara.

Pencemaran udara diakibatkan 2 aspek, yaitu aspek alami dan aspek manusia. Aspek alami pemicu tercemarnya udara diantaranya, kebakaran hutan, meletusnya gunung berapi dan kegiatan mikroorganisme. Meletusnya gunung berapi mengeluarkan abu dan gas vulkanik, kebakaran hutan menimbulkan asap yang tak bagus untuk kesehatan, kegiatan tumbuhan atau hewan yang mati atau mengurai di tanah menghasilkan bau-bau tak sedap. Akan tetapi faktor alam ini tidak sebanding dengan faktor manusia. Bahkan kebakaran juga bisa disebabkan oleh manusia itu sendiri. Begitu pentingnya menjaga alam, kita berada ditempat yang memberikan kita kehidupan, seharusnya kita menjaga dan melestarikannya. 
Penyebab pencemaran udara dapat diklasifikasikan jadi tiga yaitu oleh perkotaan serta industri, oleh pedesaan/pertanian, serta oleh sumber alami. Penyebab dari perkotaan serta industri ialah berasal dari kemajuan dan perkembangan ilmu pengetahuan serta teknologi yang menyebabkan banyaknya bermunculan pabrik-pabrik industri, pembangkit listrik, serta kendaraan bermotor. Sedangkan untuk sumber dari pedesaan atau pertanian yaitu akibat dari penggunaan pestisida sebagai zat senyawa kimia, virus dan zat-zat lain. Yang digunakan guna melindungi tanaman atau bagian tanaman. Dan untuk sumber alami bersumber dari alam, contohnya seperti abu vulkanik yang dikeluarkan akibat gunung meletus, gas vulkanik, debu yang beterbangan, bau yang tidak sedap akibat proses pembusukan sampah dan lain sebagainya (Abidin. J(2019).

Kozak serta Sudarmo dalam Purnomohadi( 1995), berpendapat bahwa ada 2 wujud emisi dari faktor ataupun senyawa pencemar udara ialah: pencemar udara primer dan pencemar udara sekunder. 1) Pencemar Udara Primer, ialah emisi unsur- unsur pencemar hawa langsung ke suasana dari sumber- sumber diam ataupun bergerak. Pencemar hawa primer ini memiliki waktu paruh di suasana yang besar pula, misalnya $\mathrm{CO}, \mathrm{CO} 2, \mathrm{NO} 2, \mathrm{SO} 2, \mathrm{CFC}, \mathrm{Cl} 2$, partikel debu, dll. 2) Pencemar Udara Sekunder ialah emisi pencemar hawa dari hasil proses raga serta kimia di suasana dalam wujud fotokimia( photochemistry) yang biasanya bertabiat reaktif serta hadapi perubahan fisik- kimiajadi faktor ataupun senyawa. Wujudnya juga berbeda/ berganti dari dikala diemisikan sampai sehabis terdapat di suasana, misalnya ozon( O3), aldehida, hujan asam, serta yang lainnya.

Faktor manusia, berbagai aktivitas manusia menyebabkan pencemaran udara. Diantaranya ialah melalui pabrik-pabrik industri, kendaraan bermotor, limbah pertanian, kegiatan pertambangan, pembakaran sampah, hingga sampah rumah tangga. Pabrik-pabrik industri merupakan penyebab terbesar pencemaran udara melaluli limbah asap pabrik atau industri. Asap-asap keluar dari cerobong ada yang tanpa proses penyaringan, sehingga zat yang keluar dari pabrik bisa dibilang zat yang berbahaya contohnya seperti karbon monoksida, hidrokarbon dan lainnya yang dapat mempengaruhi kesehatan manusia, alam dan makhluk hidup lainnya. Kendaraan roda dua dan empat merupakan alat transportasi yang begitu terpakai dalam kehidupan sekarang ini.

Asap dari kendaraan bermotor semakin lama semakin banyak mengikuti jumlah pemakainya, hal itu menyebabkan pencemaran udara. Limbah pertanian, contohnya seperti penggunaan pupuk yang terlalu berlebihan menjadikan gas amonia yang terkandung dalam pupuk tersebut keluar, dan hal itu menjadi salah satu diantara penyebab hujan asam. Kegiatan pertambangan mengambil sesuatu yang ada di dalam bumi sehingga banyak polutan yang 
dikeluarkan, seperti bahan kimia dan debu yang begitu banyak menjadikan itu sebagai penyebab pencemaran udara. Pembakaran sampah atau tumpukan sampah yang dilakukan oleh manusia tentunya akan menghasilkan bau-bau yang sangat menyengat hingga mencemari udara.

Pencemaran udara merupakan masalah lingkungan yang tentunya memiliki dampak, pada manusia, hewan, tumbuhan, material atau bangunan dan juga berpengaruh pada kualitas air hujan. Dampak pencemaran udara terhadap manusia mempengaruhi kesehatannya baik secara langsung, menahun atau kronis dan dengan gejala-gejala yang mirip. Seperti gangguan saluran pernafasan, iritasi mata, dan alergi kulit sampai pada timbulnya tumbuhan kanker paruparu. Gejala penyakit yang di akibatkan oleh pencemaran udara mempengaruhi daya kerja dan nilai produktivitas seseorang. Ada tiga cara masuknya zat polusi udara kedalam tubuh manusia, diantaranya yaitu pernafasan, pencernaan dan penetrasi kulit.

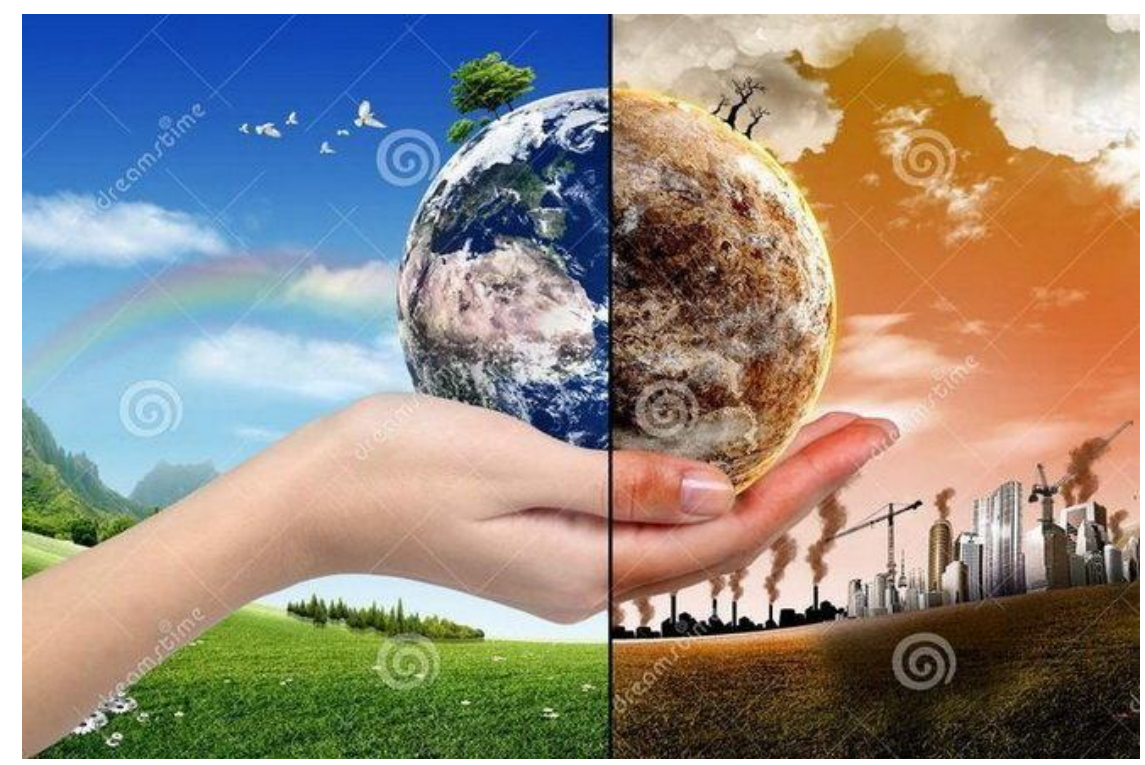

Gambar 2. Dampak pencemaran udara

Dampak terhadap flora atau tumbuhan juga mempengaruhi kesehatannya. Tumbuhan mempunyai tingkat kepekaan yang kuat dalam menerima suatu perubahan serta gangguanakibat dari pencemaran udara dan perubahan terhadap lingkungan. Polusi udara mempengaruhi tumbuhan seperti jenis tanaman, lama usia tanaman, keseimbangan nutrisi yang ada didalamnya, kondisi kesehatan tanaman, suhu, kelembaban dan penerangan. Gangguan terhadap tumbuhan yang disebabkan pencemaran udara dapat dibagi menjadi 2 kategori, yaitu primer dan sekunder. Gangguan secara primer ialah terjadinya kontak secara langsung antara polutan udara dengan bagian tumbuhan. Sedangkan gangguan secara sekunder adalah pencemaran yang terjadi pada sistem akar yang berasal dari tumpukan polutan yang ada pada tanah dan permukaan air. 
Dampak terhadap fauna atau hewan yang mempengaruhi kesehatannya. Dampak yang terjadi pada hewan akibat pencemaran udara tidak jauh berbeda dengan dampak yang terjadi pada makhluk hidup lainnya. Dampak yang terjadi kepada hewan dapat secara langsung dan tidak langsung, secara langsung apabila adanya interaksi melalui sistem pernafasan sebagaimana manusia dan secara tidak langsung melalui perantara. Misalnya seperti makanan hewan pada tumbuhan atau air yang telah terkena polutan. Saat zat pencemar udara ke atmosfer kemudian berhubungan dengan tumbuhan serta air baik melalui pengendapan atau penempelan dan pembauran, tentunya akan mempengaruhi secara langsung terhadap tetumbuhan dan mkhluk hidup di perairan sehingga dapat menjangkit pada para hewan melalui rantai makanan yang telah terbaur dengan zat pencemar atau polutan tersebut.

Dampak pencemaran udara terhadap material yaitu terhadap bangunan-bangunan, logam, batuan, kulit, dan sebagainnya dapat digambarkan sebagai akibat pencemaran udara terhadap lingkungan sekeliling. Misalnya timbulnya retakan pada permukaan dinding, yang menyebabkan terlepas dan hilangnya material dari permukaan serta berubahnya kemampuan penahan dinding. Pengaruh pencemaran udara terhadap batuan yaitu terbentuknya pelapukan batuan kapur yang biasa digunakan sebagai bahan bangunan dan pemahatan marmer. Banyak pula bangunan-bangunan yang sudah terkena dampak dari pencemaran udara, yang mana menyebabkan tim bulnya debu hingga menjadi tempat reaksi kimia yang menyebabkan pelapukan. Dengan kata lain, dampak dari pencemaran udara sangat mempengaruhi kehidupan. Baikbagi manusia, hewan, tumbuhan dan juga material sekitarnya. Apabila hal yang sedemikian itutidak diatasi, maka akan menimbulkan dampak yang lebih berbahaya lagi. Untuk itu upaya untuk mengatasi pencemaran udara perlu dilakukan. Berbagai macam cara dilakukan untuk mengatasinya. Sehingga terciptanya lingkungan yang sehat, asri, sejuk, dan nyaman bagi kehidupan.

Seperti yang telah dipaparkan, dampak pencemaran udara begitu banyak. Sehingga menimbulkan banyak permasalahan baik pada manusia, hewan, tumbuhan dan material lingkungan. Menurut Program Lingkungan PBB (UNEP) terdapat 25 masalah besar pada lingkungan yangakan ditemui oleh masyarakat pada abad ke 21 ini. Salah satunya adalah pencemaran udara, yang mana merupakan 20\% dari semua masalah yang ada. Oleh karena itu, mengatasi pencemaran udara juga merupakan suatu tantangan bagi umat manusia. Secara umum untuk mengatasi pencemaran udara ialah menyelesaikan dari akarnya yang berkaitan dengan sumber masalahnya diantaranya mengurangi konsumsi bahan bakar dan mencari bahan yang lebih ramah,pembangunan RTH (Ruang Terbuka Hijau), pembangunan bangunan serta permukiman yang berkelanjutan dan sarana transportasi yang ramah lingkungan. 


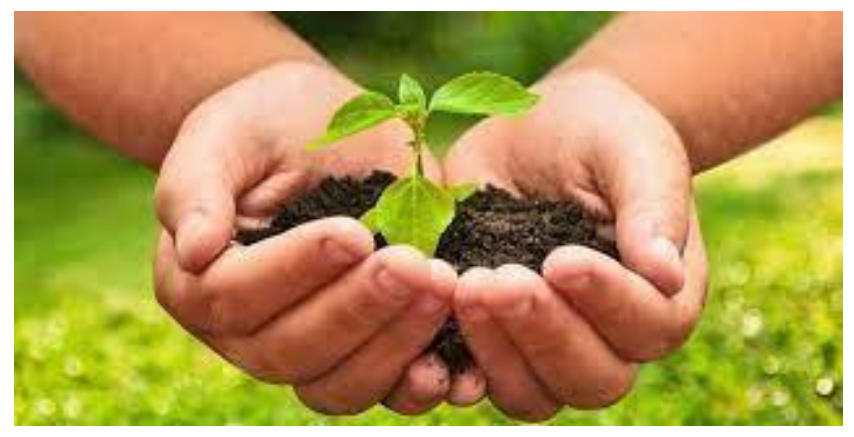

Gambar 3. Upaya mengatasi pencemaran udara

Yang pertama ialah pembangunan ruang terbuka hijau (RTH) untuk mengatasi pencemaran udara. Menurut pasal 1 ayat 10 Peraturan Daerah Kota Surabaya No. 7 Tahun 2002, yang diartikan dengan RTH ialah merupakan ruang kota yang berperan sebagai kawasan hijau semacam halaman kota, hutan kota, tamasya kota, pemakaman, pertanian, jalan hijau, serta pekarangan. RTH berbentuk hutan yakni salah satu sumber oksigen, tumbuhan pula berperan untuk menyerap karbon dioksida. Idealnya satu pohon memenuhi kebutuhan oksigen 2 orang. Sayangnya banyaknya pohon dari waktu kewaktu semakin sedikit akibat pengalihan fungsi lahan untuk pembangunan kawasan tempat tinggal dan prasarana dan sarana.

Yang kedua ialah gedung hijau, diantara sumber polusi udara ialah hasil dari buangan konsumsi energi, sehingga pengurangan pemakaian energi menjadi perihal yang begitu berarti. Pengurangan pemakaian energi bisa dicoba pada bangunan seperti gedung dengan metode desain yang memaksimalkan pencahayaan serta keadaan alami pada bagian tertentu dalam bangunan gedung tersebut. Serta juga dapat menggunakan tenaga alternatif ialah tenaga matahari. Untuk mengurangi pencemaran udara dikota, gagasan bangunan hijau bisa dipakai pada gedung dengan lansekap ataupun penghijaun vertical. Emisi CO2 dari kendaraan bermotor hendak naik nantinya ke lapisan udaraatau atmosfer atas yang akan diserap oleh tumbuhan yang terdapat pada tiap lantai gedung yang bertingkat.

Berikutnya terdapat permukiman yang berkelanjutan atau berkepanjangan, permasalahan area di kota mengakibatkan munculnya pemahaman untuk membangun kota dan permukiman yang berkelanjutan. Contohnya merupakan gerakan New Urbanism yang berkembang di Amerika Serikat. Mereka yakin kalau memperbaiki lingkungan kota akan terlaksana dengan penyusunan wilayah tempat tinggal yang berpatokan pada para pejalan kaki dengan mengurangi pemakaian motor pada permukiman yang padat, beragam fungsi tempat, bermacam-macam jenis rumah, sehingga ruang terbuka hijau untuk umum semakin meningkat, interaksi sosial terus menjadi bertambah, konservasi lahan akan terbentuk dan polusi udara akan semakin menurun. 
Yang keempat yaitu penggunaan transportasi, kemacetan lalu lintas di perkotaan menjadi penyebab tertumpuknya para pengendara sehingga menghasilkan polusi udara. Kemacetan lalu lintas bisa dikurangi dengan metode, memanajemen lalu lintas, pemaikain mode transportasi yang berpihak kepada umum serta pastinya ramah lingkungan. Serta pemakain kendaraan motor yang ramah lingkungan semacam mobil listrik ataupun mobil hidrogen. Bahan bakar alternatif untuk transportasi dan rumah tangga juga butuh dicermati. Biogas selaku bahan bakar alternatif ialah bahan bakar yang murah dibandingkan dengan bahan bakar fosil yang terus menerus semakin langka.

\section{SIMPULAN}

Jumlah penduduk yang begitu banyak, suatu perkotaan menjadi tempat yang paling banyak dihuni. Dengan berkembang dengan pesatnya ilmu pengetahuan dan teknologi, begitu banyak perubahan terjadi dalam kehidupan. Jumlah penduduk di kota lebih tinggi daripada penduduk di desa hal itu dapat menyebabkan permasalahan lingkungan diperkotaan begitu tinggi, seperti kualitas udara di desa dan di kota amat jauh berbeda. Sumber pencemaran udara lainnya berasal dari pabrik, perkantoran, rumah tangga, dan sampah. Kerusakan pada udara berarti berkurangnya daya dukung alam terhadap kehidupan yang ada dan pada gilirannya nanti akan meengurangi kualitas kehidupan manusia secara keseluruhan. Pencemaran udara merupakan salah satu masalah lingkungan terbesar yang ada di abad 21 ini.

Pencemaran udara merupakan masalah lingkungan yang tentunya memiliki dampak, pada manusia, hewan, tumbuhan, material atau bangunan dan juga berpengaruh pada kualitas air hujan. Dengan kata lain, dampak dari pencemaran udara sangat mempengaruhi kehidupan. Baik bagi manusia, hewan, tumbuhan dan juga material sekitarnya. Secara umum untuk mengatasi pencemaran udara ini ialah menyelesaikan sumber masalahnya terlebih dahulu yang berkaitan dengan pengurangan mengkonsumsi bahan bakar dan mencari sesuatu yang lebih ramah lingkungan, pembangunan ruang terbuka yang hijau dan asri, pembuatan bangunan dan permukiman yang berkelanjutan serta alat transportasi yang ramah terhadap lingkungan. 


\section{DAFTAR PUSTAKA}

Abbas, E. W. (2015). Pendidikan IPS Berbasis Kearifan Lokal. WAHANA Jaya Abadi. Abidin, J., \& Hasibuan, F. A. (2019). Pengaruh Dampak Pencemaran Udara Terhadap Kesehatan Untuk Menambah Pemahaman Masyarakat Awam Tentang Bahaya dari Polusi Udara. Prosiding SNFUR, 4(2), 3.

Adilla, Y., Adyatma, S., \& Arisanty, D. (2016). Faktor Penyebab Kerentanan Kebakaran Berdasarkan Persepsi Masyarakat di Kelurahan Melayu Kecamatan Banjarmasin Tengah. Faktor Penyebab Kerentanan Kebakaran Berdasarkan Persepsi Masyarakat Di Kelurahan Melayu Kecamatan Banjarmasin Tengah.

Basri, I. S. (2009). Jalur hijau (green belt) sebagai kontrol polusi udara hubungannya dengan kualitas hidup di perkotaan. SMARTek, 7(2).

Budiyono, A. (2010). Pencemaran udara: dampak pencemaran udara pada lingkungan. Berita Dirgantara, 2(1).

Deasy, A. (2020). Faktor penyebab terjadinya kecelakaan lalu lintas pada daerah rawan kecelakaan di Kecamatan Banjarmasin Tengah Kota Banjarmasin. JPG (Jurnal Pendidikan Geografi), 2(3), 20-37.

Deasy, A. (2017). Identifikasi faktor-faktor kerentanan terhadap kebakaran hutan dan lahan di Kecamatan Cintapuri Darussalam Kabupaten Banjar. JPG (Jurnal Pendidikan Geografi), 4(4), 23-31.

Kumalawati, R., Arisanty, D., \& Riswan, M. (2016). Analisis Lokasi Tempat Penampungan Sampah Sementara (Tpss) Kecamatan Alalak Kabupaten Barito Kuala, Kalimantan Selatan. Jurnal SPATIAL Wahana Komunikasi dan Informasi Geografi, 15(1), 19-22.

Kwanda, T. (2003). Pembangunan permukiman yang berkelanjutan untuk mengurangi polusi udara. DIMENSI (Journal of Architecture and Built Environment), 31(1).

Rahardjo, P. (2012). Pengendalian Pencemaran Udara DI Perkotaan Di Kota Jakarta Dengan Pendekatan Ekosistem. In Seminar Nasional Avoer.

Simandjuntak, A. G. (2013). Pencemaran udara. Buletin Limbah, 11(1).

Sundari, E. S. (2010). Studi untuk menentukan fungsi hutan kota dalam masalah lingkungan perkotaan. Jurnal Perencanaan Wilayah dan Kota UNISBA, 6(2).

Utomo, M. I. H. H., Udiansyah, U., \& Naemah, D. (2020). PERSEPSI MASYARAKAT TANI TENTANG PENGELOLAAN LAHAN TANPA BAKAR DI LANDASAN ULIN UTARA BANJARBARU KALIMANTAN SELATAN. Jurnal Sylva Scienteae, 2(4), 745-756. 